\title{
ANZTLA Queensland Chapter Report 2014
}

$\mathrm{L}$

ibraries under construction! Building in progress! - That's the report in brief from all the ANZTLA Q members this year.

\section{Real and virtual!}

Not only is the Queensland Theological College planning a new bricks and mortar library, but for most of our members, virtual walls have expanded with ebooks added to traditional collections. In the words of Annette McGrath, "2014 has been a year of building, building collections and building for the future”. In building our virtual libraries, we've found that the convenience of ebooks far outweighs initial complications with authentication and access.

A new Principal at the Brisbane School of Theology has encouraged the substantial acquisition of current publications, especially in New Testament studies. After describing the fine religious art collection donated to the Roscoe Library, Eve enthused that: "It's been a full-on year but a good one" at St Francis. Donations to the Malyon College Library will be catalogued first before shipping them to a theological college in the Solomon Islands at the beginning of next year. Ian Stoodley is helping Jill with this big job. Meanwhile, ACU have decided to no longer take donations. St Paul's Seminary is being redeveloped to include an archive. The transfer of archival material is partially done and will continue next year.

The Sunshine Coast Theological College (STC) Library subscribed to ATLA for the first time this year and the Brisbane School of Theology (BST) is planning to do so. STC and BST are both in the process of planning new library management systems. The choices are Koha or Liberty.

\section{New \& renewed!}

'It's a great job," says Stephen Morton at Christian Heritage College (CHC), where he's restructured staffing and opening hours; and at Trinity there's a new Learning \& Teaching Librarian, a job shared by Anna Lagos and Lyndelle Gunton. Joining ANZTLA this year was only part of Nica's 'rollercoaster year' as the newly appointed liaison librarian in theology at ACU. Our bright and colourful Sarah Howard left us for a new team at Queensland University of Technology.

\section{Show \& tell!}

In contrast to Kevin Hannah's anecdotes at the 2014 ANZTLA conference, CHC now raves about Steve's innovative displays and Trinity has brash new orange LIBRARY signage. Eventbrite is being successfully used by St Francis and ACU for promotional purposes. Annette's been inspired with new ideas after her attendance at the ATLA Conference in New Orleans. The local chapters of ANZTLA and ANZATS met together twice this 
year to exchange ideas and, at the last meeting, Trinity and ACU librarians presented their stories on how librarians are supporting online learning environments.

We're happy with that: Andree Pursey ( Nazarene Theological College), Angela Gear (Sunshine Coast Theological College), Annette McGrath (Queensland Theological College), Eve James \& Susan Thomas (St Francis Theological College), Helen Johnston (Brisbane School of Theology), Jill Walker (Malyon College), Nica Tsakmakis (Australian Catholic University), Stephen Morton (Christian Heritage College), Alethea Hubley, Anna Lagos, and Lyndelle Gunton (Trinity Theological Library).

"In building our virtual libraries, we've found that the convenience of ebooks far outweighs initial complications with authentication and access." 